\title{
Newspapers in Bioethics Education: A Case Study ${ }^{i}$
}

\author{
Melike Özer Keskin ${ }^{1, *}$, Esma Aksakal ${ }^{2}$ \\ ${ }^{1}$ Department of Biology Education, Gazi Faculty of Education, Gazi University, Turkey \\ ${ }^{2}$ Department of Biology Education, Institute of Educational Sciences, Gazi University, Turkey
}

Copyright $\bigcirc 2019$ by authors, all rights reserved. Authors agree that this article remains permanently open access under the terms of the Creative Commons Attribution License 4.0 International License

\begin{abstract}
While the idea of using newspapers in education dates back to as early as the 1890's. It has been significantly promoted in various circles since the first half of the $20^{\text {th }}$ century. Newspapers are considered to be important learning materials as they focus on current affairs, address a wide range of audiences, and provide students with a learning environment other than the classroom setting. Increasing numbers of studies highlight the effectiveness of it. The present study investigates the effects of the use of news items from newspapers as learning materials in bioethics education. The internet archives of the newspapers with the highest circulation in the national press were screened for news items on surrogacy. One was selected for the process of bioethics education. The study was implemented with a total of 112 pupils in their tenth year at a public vocational secondary school of health services in Ankara. The bioethics education model developed by [13] was used in the study. At the end of the implementation, semi-structured interviews were held with pupils in order to identify their opinions on the processes of bioethics education and the use of news in the classroom.
\end{abstract}

Keywords Bioethics Education, Newspapers, Student Opinions, Surrogacy

\section{Introduction}

In 1970, Van Rensselaer Potter coined the term 'bioethics' from 'bios' (life) and 'ethos' (morals) [17]. Bioethics studies the social impact of developments in biology and related sciences from an ethical point of view. On the one hand, humans find solutions to many problems thanks to the rapid advances in biological sciences but, on the other hand, they also find themselves in the centre of ethical debates because of these advances. While humans must adapt to scientific and technological developments, they may at times have to make decisions and choices as regards these developments [4].

Today, it is no longer sufficient just to mention the breakthroughs in biology and related sciences in class; the ethical dimensions of these developments also need tackling in educational processes. Bioethics education in schools involves raising students' awareness of ethical issues relating to life itself and enabling them to come up with solutions to such problems [2]. In the process of bioethics education, students are made to discuss what could be done in such eventualities and find solutions [16]. Studying the social impact of biological sciences and their applications in biology and science classes is important in that it both informs students of the applications in question and raises their awareness. Only through a science education involving bioethics educational processes can students correctly interpret science-society interactional situations and make informed decisions in such situations $[5,6]$.

In today's world, mass communication tools (newspapers, magazines, books, radio, television, computer, the internet, telephone, etc.) are of utmost importance as sources of information [7, 20, 27, 28]. At the same time, mass media presents itself as an effective set of tools in forming public opinion about certain policies, their effects, and what needs to be done [26].

Amongst these mass communication tools, newspapers have an important status as regional and global sources of information and an important place in the process of education. Mass media has been cited as people's preferred source of scientific information following the completion of formal education. [1, 10].

According to data from 2017, there are 2,474 newspapers in Turkey with a combined circulation of 15.59 million. In general, the online versions of newspapers provide people with easier access to the national press [22].

Newspapers are potentially effective tools in the learning and teaching process, as they are the most up-to-date source of information on both regional and global topics $[10,21]$. While the idea of using newspapers in education dates back to as early as the 1890's, it has been significantly promoted in various circles since the first half of the 20th century. Newspapers have been cited as a useful educational resource as they improve students' vocabulary, visually enhance the teaching resources in schools, can 
serve as the first step in certain life skills, provide guidance for current course books can be cut, stuck, folded, and marked, provide a link with real life, and present interesting news articles [3, 19].

Newspapers are considered to be important learning materials as they focus on current affairs, address a wide range of audiences, and provide students with a learning environment other than the classroom setting. Newspapers are used for teaching purposes in many schools in various countries throughout the world and an increasing number of studies highlight the effectiveness of this learning material. Teachers can use newspapers in the classroom for a number of purposes including comprehension, teaching critical thinking, and raising students' awareness of themselves, their society, and the world. The importance of science-related topics in the media has been highlighted as regards science literacy, the nature of science, and the public understanding of science; and these topics have also been demonstrated to improve readers' discussion skills. The use of newspapers in education also brings up the issues of social responsibility, science for the society, lifelong learning, and science in the press [15, 20, 23, 25, 28].

The use of news items in the classroom has been incorporated in curricula in order to increase the use of newspapers in education. For instance, with the 'Newspapers in Education' (NIE) programme in the US, teachers are offered courses on how to use newspapers and presentations of sample implementations, and students are given newspapers [15]. Similarly, the Ministry of National Education in Turkey published a supplementary programme on 'using newspaper clippings as part of the teaching-learning processes in years 4 to 8 in primary education' in the 2008-2009 school year. Newspapers have come to be seen as the quickest way to reach the most current information and the most varied class implement. News articles have been found to be useable as learning materials in effective teaching-learning settings, and teachers have been encouraged to make use of them. As with other subjects, newspapers are also a source of biology-related news items [10]. Teachers may use newspapers in different ways in the science classroom. The most common way would be to use them as sources of information and their content for discussion. Newspapers are important in making a link between school science and science in everyday life [20]. The news content also highlights the link between the critical and reflective objectives of science education [24].

The present study makes use of news items from newspapers as learning materials in bioethics education.
The selected news items from the newspapers was selected for the process of bioethics education.

\section{Materials and Methods}

Qualitative research techniques were used to collect the data for this study, which looks at newspapers as learning materials in bioethics education. This study was designed as a case study, a type of qualitative research. Purposive sampling was used to select the research participants. The study was implemented in the 2017-2018 school year with a total of 112 pupils in four classes, all in their tenth year, at a public vocational secondary school of health services in Ankara. 74 girls (66.07\%) and 38 boys (33.93\%) took part in the study. The implementation took four weeks as planned.

In the study, the process of bioethics education was implemented by means of a news item on surrogacy, which strikes as a controversial subject in Turkey as well as in the rest of the world. The internet archives of the newspapers with the highest circulation in the national press (Hürriyet, Posta, Takvim, Yeni şafak, Habertürk, Milliyet, Cumhuriyet) were screened for news items on surrogacy. A total of 230 news items that had appeared on surrogacy over the past decade were studied. The news item in the Milliyet of 03.08.2014 entitled 'Baby with Down Syndrome Abandoned by Parents' was selected for the study because of its interesting nature conducive to a debate of surrogacy from multiple perspectives.

The process of bioethics education through newspapers was implemented in line with the 'Bioethics Education Process Model' developed by [13] (Figure 1). During the implementation of the model, the pupils were made to read the news item first, which was followed by the further stages in the model. With this model, developed with bioethics education in mind, the basic stages used in the ethical decision-making process were taken into consideration. The model is structured around seven stages geared towards considering the ethical dilemma put forward by the teacher and making a decision. The model's core stages of studying the preliminary information, adopting individual perspectives / values, having small group discussions, holding a class discussion, concluding the discussion, and summarizing were completed, and the optional stages of expansion and application were left to the pupils. The Bioethics Education Process Model stages completed by the pupils are presented in detail in Figure 1. 


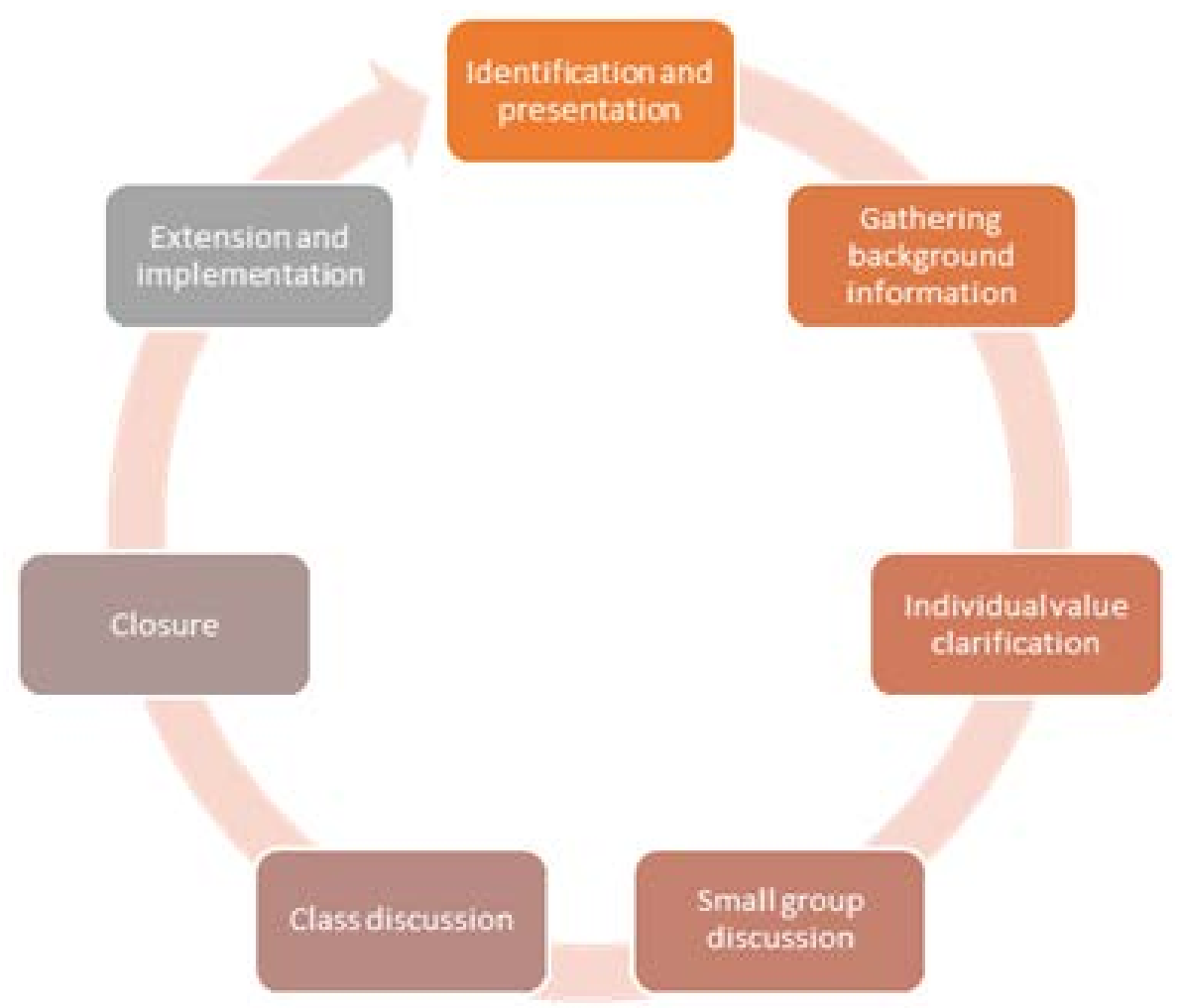

Figure 1. Bioethics Education Process Model [13]

Identification and Presentation: At this stage, the news story that had been selected for this activity (Appendix 1) was photocopied and handed out to the pupils who were asked to read it. They were given enough time to spot the ethical dilemma and to explain the context of the ethical debate. At this stage, the pupils were expected to explain why the event in the news story was a dilemma.

Gathering Background Information: This stage involved providing pupils with the basic information that they may need in the decision-making process. In this context, what the pupils knew about surrogacy and Down syndrome was questioned and they were given basic information about the topics by the classroom teachers. In addition, the students did some reading about the topics. At this stage, the pupils were made to see the link between the dilemma in the news story and scientific facts.

Individual Value Clarification: At this stage, the pupils were given time to realize their own values and opinions about the dilemma in the news story. They were asked to consider the event from the window of their own values.

Small Group Discussion: In this process, small groups of four to six pupils were formed in the class. With four to seven groups in each class, there were a total of 24 groups in all four classes. The small groups were asked to discuss the issue. These small group discussions were intended to create an environment where all pupils could freely voice their own opinions. At this stage, the pupils were enabled to both realize their own values and notice different opinions and perspectives in the ethical decision-making process. In each group, a pupil was selected to take the minutes so that the points discussed by the small groups would be fully considered in the larger discussion as well. In the group discussions, it was ensured that the ethical issue was properly identified, scientific facts were taken into account, and the issue was tackled from different stakeholders' perspectives, while at the same time the pupils were enabled to fully grasp the subject.

Class Discussion: At this stage, the points discussed by the small groups were considered by the whole class with the help of the minutes taken. During the presentation of the small group conclusions, the pupils were encouraged to ask questions to other groups, to consider conflicting opinions, and to evaluate other groups' views. In this process, it was ensured that the issue was tackled from all stakeholders' perspectives and that the solution found was fair for all parties involved.

Closure: At this stage, the conclusions reached by the pupils in the small and large group discussions were highlighted and the topic was summarized in light of these views. Care was taken to summarize all possible conclusions, without pressurizing the pupils to reach a unanimous conclusion. The process was reviewed and summarized with the participation of the whole class.

Extension and Implementation: This optional stage was not part of the study. This stage could serve as reinforcement through alternative activities for the pupils 
and application in different fields.

In group and class discussions alike, the importance of tackling the ethical dimension of the issue from different stakeholders' perspectives was emphasized. During implementation, the small group and class discussions were studied through content analysis. Following implementation, semi-structured interview questions were used to elicit the opinions of pupils with different academic performances on the bioethics education processes implemented and the classroom use of the news story. For the semi-structured interviews, a total of seven lower, middle, and upper level students (S1, S2, ... S7) were selected. As one of the researchers was also the biology teacher of the classes in the study, the selection of the pupils was based on the teacher's views as well as their general school performance and biology subject grades. In the semi-structured interviews, the following questions were put to the pupils:

- What do you think about the discussion we had in class?

- Did you have any prior knowledge about surrogacy?

- Was the topic interesting?

- How do you feel about the use of news stories from newspapers in biology classes?

The interviews were audio-recorded and later transcribed for content analysis. What the pupils said in the group and class discussions as well as the semi-structured interviews was independently studied by the two researchers, with the data coded and themes formed. Following content analysis, agreement was reached on the themes of method, the stakeholders involved, advantages of the practice, disadvantages of the practice, and its legality.

\section{Findings}

In the group and class discussions held by the pupils, the concept of surrogacy was tackled in terms of method, the stakeholders involved, advantages of the practice, disadvantages of the practice, and its legal status in our country and in the rest of the world.

\subsection{Method}

During the discussions, the pupils were found to consider the concepts of biological parents and surrogate mothers.

Group 13: '.. instead of adopting, it might seem like a better idea for the mother to place her eggs and her husband's sperm inside a surrogate mother ...'

Group 15: 'The Austrian couple ... didn't want to adopt. They wanted their children to carry their own genes. That's why they hired a surrogate mother.'

Group 24: ' $\ldots$ the sperm processed in a lab and placed inside a second mother's womb obviously (the baby) belongs to the biological parents and not the surrogate mother. That's why the child - with or without Down syndrome - belongs to the biological family.'

S1: ' $\ldots$ in the end, the sperm and the eggs processed in a lab are placed inside a surrogate mother's womb, and that's why the child belongs to the biological parents and not the surrogate mother. Ultimately, it's their child.'

In the group discussions, the pupils were found to correctly understand the method of surrogacy practices. Upon studying the pupils' responses in the semi-structured interviews, it turned out that some pupils had limited prior knowledge of surrogacy methods while others learnt about them in the course of the activities.

S1: '... I knew (about surrogacy). But then again, there were a few things that I didn't know. I've now learnt about them.'

S3: 'I didn't know as much about surrogacy before. I also know now that there are such things happening.'

S5: '... I knew a few things about surrogacy. But I've got more detailed information now.'

\subsection{Stakeholders}

In the bioethics education process, it is important that the issue is approached from the perspectives of all stakeholders. In the small group and class discussions, the pupils were found to identify the stakeholders of the news story as the rich Austrian family, the poor surrogate mother, the surrogate mother's family, and the baby born with Down syndrome. The evaluation of the situation in the group and class discussions can be exemplified as follows:

Group 2: '... If I was the child with Down syndrome and my parents abandoned me just because of that, I'd never forgive them.'

Group 4: '... If I was the Austrian family, I'd have my kid treated and cover the costs as much as I could. If that didn't work, I'd leave him in a hospice or with a caregiver. Or leave him with the surrogate mother in return for a monthly salary'.

Group 5: '.. If we were the surrogate mother, we'd sue the family. We'd stand up for the kid's rights. We'd ask for alimony for the kid's needs and treatment costs. We wouldn't give the kid back to a family that didn't want him in the first place. We'd do our best to raise him with love and care, same as our own kids. That's what would happen unless we really needed the money'.

Group 6: '.. If I was the Austrian couple, I wouldn't go for surrogacy in the first place - I'd adopt a needy child. I'd never abandon a child of my own flesh and blood. Just the opposite: I'd do anything for his treatment because I was rich.'

Group 7: '... In surrogacy, you carry some couple's baby for nine months but then, if the baby's sick, they refuse to take it. That's not right. You pay to get a baby, but if you don't like it, you just leave it, as if ordering 
goods. If you want to have kids, then you should take care of those, too. It's amazing that the surrogate mother takes care of the child despite all the difficulties when the real family don't want the child.'

Group 8: '... If the child's unhealthy, they should still take it because the problem could be due to them. If the surrogate mother's husband is poor and uses her for extra income, then that's unacceptable. But if he's dead and the surrogate mother has no other choice, then it could be considered positive.

As can be seen, in the bioethics education process, the pupils approached surrogacy from the perspectives of different stakeholders.

\subsection{Advantages}

In the group and class discussions, surrogacy was presented as advantageous in that it was an alternative way to have children for couples who could not ordinarily do so for health reasons. Furthermore, surrogacy was also considered as a way to have children for women who avoided pregnancy for various reasons.

Group 8: '... If the mother has no womb, it might be a good idea to go for surrogacy. But if the mother rejects pregnancy because she doesn't want her body to be deformed, it's so wrong.'

Group 9: ‘... Some people may be working as models and not want to go through pregnancy for that reason.'

Group 10: ‘... Even though surrogacy isn't desirable from the religious point of view, it is quite a good thing for married couples who can't have babies. ... Those who want to have kids but can't for professional or other reasons could go down this road.'

\subsection{Disadvantages}

In the bioethics education process, it is important to consider the disadvantages and possible risks of an issue as well as its advantages. In the group and class discussions held, it was observed that the disadvantages and risks associated with surrogacy were also taken into consideration. In the discussions and individual interviews, pupils pointed out the advantages of surrogacy, such as the chance to have a baby for those who can't, as well as its disadvantages and risks such as abusing the practice for money, complications and consequences during pregnancy and birth giving, who gets to decide in the case of complications, and the surrogate mother's rights.

Group 3: '... I would have the baby’s biological parents sign a document accepting to take their child from the surrogate mother whatever the circumstances might be. ...'

Group 7: ‘... In surrogacy, you carry some couple’s baby for nine months but then, if the baby's sick, they refuse to take it. That's not right. You pay to get a baby, but if you don't like it, you just leave it, as if ordering goods. ...'

Group 8: '... That's why surrogacy might be a good idea for those who need the money but it comes with emotional, psychological, and physical disadvantages.'

S2: '... I've heard about quite large sums of money being exchanged for surrogacy, which kind of makes it a commercial activity.'

S5: '... In our class discussion, we talked about what a surrogate mother might go through, the surrogate mother's rights, the real mother's rights, the children's status, and why they would go for something like that. ... If I were the surrogate mother's husband, I wouldn't want my wife to do something like that. Who would be responsible for the problems and risks during my wife's pregnancy? ... In the end, things may happen outside our control. Who would take the blame in such cases?'

S6: '... It's so commercial when it's done for money. The high amounts of money involved ring the alarm bells, too. ... Who determines the surrogate mother's rights and the real family's rights? Is there such a law? If there is, what are their rights? If there's no limit to the money involved, it sounds like a trade. ...'

It can be seen that the pupils approached the disadvantages and risks associated with surrogacy from a large perspective.

\subsection{Legal Status}

It could be argued that the pupils' awareness of the legal status of surrogacy in our country and in the rest of the world was increased.

Group 1: '... It may be legal in our country because some people may be working as models and not want to go through pregnancy for that reason. It shouldn't be legal for those who have no valid reason. For those who do, it should be legal.'

S2: 'Surrogacy like in this news story could be seen as wrong in our country but this happened in another country where it's legal and considered normal. ... I've found out there are some countries where it's legal and others where it may be legalized.'

S4: 'It's banned in Turkey but apparently so much money is involved in this activity abroad. I had no idea.'

\subsection{Using Newspapers in Biology Classes}

The semi-structured interviews conducted with selected pupils with different academic performances sought to reveal what the pupils thought about the use of newspaper articles in the classroom. Below are some examples of the pupils' opinions:

S1: '... If news items like this one were used in both biology and other subjects, the lessons would be more fun and we would grow more aware of things. ...'

S2: '... Such news stories in the biology lessons have been useful because we have come to realize what was 
happening around the world. It's been positive. It could make monotonous lessons more interesting. ...'

S3: ' $\ldots$ This news story has greatly increased my awareness. I think my classmates feel the same way, too. It's been extremely useful for us. It made a huge difference, broke up the routine, and even made our uninterested classmates participate in the class. I really enjoyed it. ...'

S4: '.. I think various news items like this should be used. We learnt about genetic engineering, cloning, and genetic diseases, but we're more likely to remember things when we see them in context like newspaper articles. It's been more interesting. It's aroused our curiosity - now we want to go home and find out more about the topic. ...'

S5: '... I think it was good. If the lessons were taught this way, the subjects would be more understandable and realistic. It was a surprising and impressive news story. ...'

S6: '... It's good to do the biology lessons with news articles like this. It attracted everyone's attention. Like, we're really curious about what happened in the end. I wonder what's happened in all those years. News stories related to our topics make those topics more interesting. ...'

S7: '... The lesson was very good. At the moment, the classes are really boring in our school. There's no variety. It was exciting. None of us here knew anything about this topic. ... Teaching the lessons with such news stories is very nice (and) logical. I think (such activities) should remain. ...'

As can be seen from the statements above, the pupils generally thought of the use of news stories in the classroom in a positive way: it increased their interest in the lesson, raised their awareness of the topic, and made the topic more understandable; it was also fun, informative, curiosity-arousing, and thought-provoking.

\section{Conclusions}

Raising individuals with $21^{\text {st }}$ century skills seems to be the most important goal of education. While these skills can be grouped in different ways, they basically include creativity, critical thinking, problem-solving, decision-making, learning to learn, communication, collaboration, and personal and social responsibility $[9,18]$. It has been argued that the use of newspapers in education is effective in improving these skills. It has also been suggested that, in the teaching of various disciplines, newspapers increase students' interest in the lesson and turn them into critical readers [3; 14]. While newspapers enable students to access information, they also allow them to have a critical look at this information and apply it in their lives [8].

Discussion-based bioethics education enables students to be informed about a topic while at the same time allowing them to correctly analyse the topic, think critically, apply reasoning, think judgmentally and reflectively, and analyse and evaluate alternative points of view. With ethics education, individuals are expected to evaluate any topic from the perspectives of different stakeholders, study its potential costs and benefits, consider the social, political, and legal issues involved, and use ethical values in their thinking and decision-making [11;12]. These skills serve to raise individuals who can think critically, apply their knowledge to their lives, make decisions in the face of problems, and grasp the connection between science, technology, and society.

In view of their future roles, bioethics education can ensure that today's youths have increased levels of awareness of sociological issues and grow conscious of the advances in biological sciences and the applications of these advances.

The present study was about the use of newspaper articles in bioethics education and, upon considering its implementation process and the student statements, it can be suggested that the issue was approached from the perspectives of different stakeholders, potential costs and benefits were weighed, the problem was tackled from social and legal dimensions, and a decision was made accordingly. In this context, newspaper articles can be said to have contributed to the bioethics education process implemented. Newspapers are quite rich resources in terms of news about various sociological issues. As learning materials, newspapers can be used in a similar way in an effective bioethics education process. 


\title{
Appendix
}

\section{Down sendromlu bebeklerini bırakıp gittiler}

\author{
03.08.2014 - 10.06 | Son Guncelleme: 03.08.2014-10.42
}

\section{Taylandlı genç bir kadının hayatı taşıyıcı annelik yapmasının ardından kabusa döndü. 21 yaşındaki genç kadın Avustralyalı bir çiftin bebeklerine hamile kaldı. Ancak genç kadın 1 yerine 2 bebek dünyaya getirince işler karıştı.}

Avustralyalı çift çocuk sahibi olmak için Tayland'da Pattharamon Janbua isimli taşıyıcı bir anneye 11 bin 700 dolar odedi. Ancak taşıyıcı anne bir yerine iki bebek dūnyaya getirince ģift bebeklerden birini down sendromlu olduğu için almadı. Boylece bebeğe bakacak durumu da

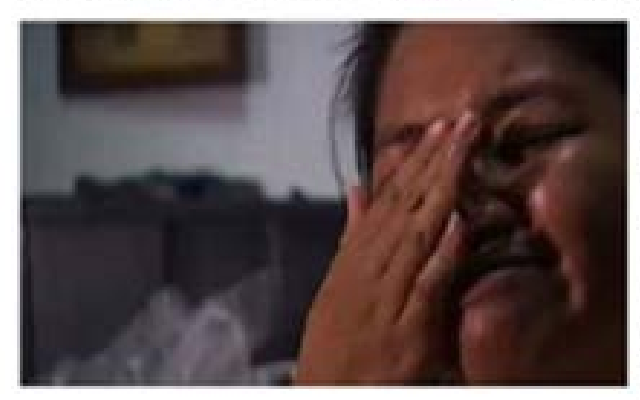
olmayan genç anne çiftin down sendromlu bebeğiyle baș bașa kaldı.

Iki bebekten kız olanı sağıklıydı. Ancak erkek bebek down sendromluydu ve kalbinde sorunlar vardı. Avustralyalı çift sağlıklı olduğu için kız bebeği alıp gitti. Down sendromlu bebeği ise genç taşıyıcı anneyle birakarak olame terk etti.

Tașıyıcı anne Gammy ismini verdigi bebeği kurtarmak için internet uzerinden bir yardım kampanyası bașlattı. Kısa surede dunya basınının da ilgisini çeken genç kadın bebeğin hayatta kalması için gereken 25 bin dolardan çok daha fazlasını 65 bin dolar kadar bir miktan toplamayı başardı.

Pattharamon Janbua'nın 6 yaşında bir oḡlu ve 3 yanında bir kızı var. Ailesinin bırakıp gittıği Gammy bebeği ise kendi çocuğu gibi gördūgūnù, onu çok sevdiğini ve 9 ay boyunca karnında taşıdığını söylüyor.

\section{REFERENCES}

[1] Chowdhury, S. \& Halder, S. (2016). Dissemination through Newspaper Daily. Journal of Education and Practice, 7(7), $1-12$.

[2] Dawson, V. M. (1999). Bioethics education in the science curriculum: evaluation of strategies for effective and meaningful implementation. Ph.D. Thesis, The Curtin University of Technology.

[3] Deveci, H. (2005). Sosyal Bilgiler Dersinde Gazete Kullanımı. The Turkish Online Journal of Educational Technology - Tojet, 4(3), 159-166.
[4] Erol Işık, N. (2003). Bilim, etik ve eğitim ilişkisi üzerine. Türkiye mühendislik haberleri, 423, 1.

[5] Haynes, F. (2002). Eğitimde etik. (Çev. Kunt Akbaş, S.). Ayrıntı Yayınları: İstanbul

[6] Keskin Samanc1, N. (2009). Biyoetik eğitimi kapsamında ortaöğretim öğrencilerine yönelik 'biyoetik değer envanteri' geliştirilmesi. Doktora Tezi, Gazi Üniversitesi Eğitim Bilimleri Enstitüsü.

[7] Kocadaş B. (2004)., Kitle iletişim Araçları Eğitim İlişkisisi. Dinbilimleri Akademik Araștırma Dergisi IV, 2, 129-134.

[8] Kösebalaban Doğan, N. ve Taşköprülü, Ş. S. (2008). Meslek Yüksekokulu Öğrencilerinin Medya Okuryazarlı̆̆1 Kavramı Bağlamında Medyayı Kullanmaya Yönelik Tutumlarının Belirlenmesi, İstanbul Üniversitesi İletișim 
Fakültesi Dergisi, s.81-96.

[9] Kylonen, P. C. (2012). Measurement of 21st century skills within the common core state standards. Paper presented at the Invitational Research Symposium on Technology Enhanced Assessments, May 7-8.

[10] Özay Köse, E.(2008). Gazete Haberlerinin Biyoloji Eğitiminde Kullanımı. Kuramsal Eğitimbilim, 1 (2), 84-91.

[11] Pedretti, E. (1999). Desicion making and STS education: Exploring scientific knowledge and social responsibility in schools and science centers through an issue-based approach. School Science and Mathematics, 99, 174-181.

[12] Pieper, A. (1999). Etiğe Giriş, (Çev. Atayman, V. ve Sezer, G.). Ayrıntı Yayınları: İstanbul. (1994 yılında yapılan 3. basımdan çevrilmiştir.)

[13] Smith, W. (1992). A process: Framework for teaching bioethics, Woodrow Wilson Biology Institute. Web: http://www.woodrow.org/teachers/bi/1992/teaching_bioeth ics.html

[14] Street, C. (2002). Teaching with the newspaper. Social Studies. 93 (3), 131-134.

[15] Sunal, C. S. \& Haas, M. E. (2002).Social studies for the elementary and middle grades. A constructivist approach. Allyn and Bacon. Boston.

[16] Taylor,S.N.(2009). Bioethics in the classroom. Retrieved 20th September 2018 from http:// www.accessexcellence.o rg/ LC/TE /BE/.

[17] Ülman, Y. I. (2010). Etik, biyoetik, hukuk: temel kavramlar ve yaklaşımlar. Acıbadem Üniversitesi Sağlık Bilimleri Dergisi, 1(1), 1-4.

[18] Yaşar, Ş.(1998). Yapısalcı kuram ve öğrenme-öğretme süreci. Anadolu Üniversitesi Eğitim Fakültesi Dergisi, 8, (1-2), 68-75.

[19] Tangülü, Z. (2013). The use of newspaper in 8th grade revolution and kemalism courses and its effects on students' attitude and success. Turkish Studies - International Periodical For The Languages, Literature and History of Turkish or Turkic Volume 8/5 Spring 2013, p. 779-788.

[20] Ruth Jarman \& Billy McClune (2002) A survey of the use of newspapers in science instruction by secondary teachers in Northern Ireland, International Journal of Science Education, 24:10, 997-1020, DOI: 10.1080/095006902100 95311

[21] Chowdhury,S. \& Halder, S. (2016). Educational dissemination through newspaper daily. Journal of Education and Practice 7(7), 1-12.

[22] Türkiye İstatistik Kurumu (2018). Yazılı Medya İstatistikleri, 2017 Haber Bülteni. Retrieved 13th April, 2019 from www.tuik.gov.tr.

[23] Çuhadar, E. Ünal, F. (2018). Evaluation of Contribution of Local Newspapers to Lifelong Learning (Example of Bartın Province). Universal Journal of Educational Research 6(3): 478-490. DOI: 10.13189/ujer.2018.060314.

[24] Carver, R.B., Wiede, E.F. \& Breivik, J. (2014), Frame Analysis in Science Education: A Classroom Activity for Promoting Media Literacy and Learning about Genetic
Causation. International Journal of Science Education, Part B, 2014 Vol. 4, No. 3, 211-239, http://dx.doi.org/10.1080/ 21548455.2013.797128.

[25] García-Carmona, A., \& Acevedo, J. A. (2016). Learning about the nature of science using newspaper articles with scientific content: a study in initial primary teacher education. Science \& Education, 25(5-6), 523-546.

[26] Nwabueze, C. \& Egbra, S. (2016). “Newspaper Framing of Climate Change in Nigeria and Ghana." Applied Environmental Education \& Communication 15 (2):11124.

[27] Jarman, R. \& McClun, B. (2001) Use the news: a study of secondary teachers' use of newspapers in the science classroom, Journal of Biological Education, 35:2, 69-74, DOI: $10.1080 / 00219266.2000 .9655745$.

[28] Akcay,H. Kapıcı, H.Ö. \& Yager, R.E. (2017). Using Newspapers and Advertisement as a Focus for Science Teaching and Learning. H. Universal Journal of Educational Research 5(1): 99-103, 2017 http://www.hrpub.org DOI: 10.13189/ujer.2017.050112.

i This study was presented at the IKSAD $2^{\text {nd }}$ International Social Sciences Congress held in Gaziantep, Turkey (November 22-25, 2018). 